\title{
Differences in the risk of cervical cancer and human papillomavirus infection by education level
}

\author{
S Franceschi",', M Plummer', G Clifford', S de Sanjose ${ }^{2}$, X Bosch $^{2}$, R Herrero ${ }^{3}$, N Muñoz $^{4}$ and S Vaccarella' \\ for the International Agency for Research on Cancer Multicentric Cervical Cancer Study Groups and the \\ International Agency for Research on Cancer Human Papillomavirus Prevalence Surveys Study Group ${ }^{\mathbf{5}}$ \\ 'International Agency for Research on Cancer, 150 cours Albert Thomas, 69372 Lyon cedex 08, France; '2Servei d'Epidemiologia i Registre del Cancer, \\ Institut Català d'Oncologia, Hospital Duran i Reynals, Av. Gran Via, s/n. Km 2.7, 08907 L'Hospitalet de Llobregat, Barcelona, Spain; ${ }^{3}$ Proyecto \\ Epidemiológico Guanacaste, Fundación INCIENSA, Torre La Sabana, 300 Oeste del ICE, Piso 7, Sabana Norte, San José, Costa Rica; ${ }^{4}$ Instituto Nacional \\ de Cancerología, Calle I No. 9-85, Bogota, Colombia
}

BACKGROUND: Cervical cancer risk is associated with low education even in an unscreened population, but it is not clear whether human papillomavirus (HPV) infection follows the same pattern.

METHODS: Two large multicentric studies (case-control studies of cervical cancer and HPV prevalence survey) including nearly 20000 women. GP5 + /GP6 + PCR was used to detect HPV.

RESULTS: Education level was consistently associated with cervical cancer risk (odds ratio (OR) for 0 and $>5$ years vs $\mathrm{I}-5$ years $=1.50,95 \%$ confidence interval $(\mathrm{Cl}): 1.25-1.80$ and $0.69,95 \% \mathrm{Cl}: 0.57-0.82$, respectively, $P$ for trend $<0.000 \mathrm{I}$ ). In contrast, no association emerged between education level and HPV infection in either of the two IARC studies. A majority of the women studied had never had a Pap smear. The association between low education level and cervical cancer was most strongly attenuated by adjustment for age at first sexual intercourse and first pregnancy. Parity and screening history (but not lifetime number of sexual partners, husband's extramarital sexual relationships, and smoking) also seemed to be important confounding factors.

CONCLUSION: The excess of cervical cancer found in women with a low socio-economic status seems, therefore, not to be explained by a concomitant excess of HPV prevalence, but rather by early events in a woman's sexually active life that may modify the cancercausing potential of HPV infection.

British Journal of Cancer (2009) I 0 I, 865-870. doi: I0.1038/sj.bjc.6605224 www.bjcancer.com

Published online 4 August 2009

(C) 2009 Cancer Research UK

Keywords: cervical cancer; human papillomavirus; education; age at first sexual intercourse; age at first pregnancy

Cervical cancer risk is associated with a low socio-economic status (SES), as defined by education or income levels (Parikh et al, 2003). The reasons for the association are not fully understood but are thought to include a higher prevalence of cervical cancer risk factors, such as inadequate cervical cancer screening (Khan et al, 2005), high parity (International Collaboration of Epidemiological Studies of Cervical Cancer, 2006), and possibly high-risk sexual behaviour (International Collaboration of Epidemiological Studies of Cervical Cancer, 2009; Louie et al, 2009) among women with a low SES (de Sanjose et al, 1997).

It is now believed that the majority of cervical cancer is preceded by a long-term infection with high-risk types of the human papillomavirus (HPV), a sexually transmitted infection (Schiffman et al, 2007). High prevalence of HPV in women with a low SES has been shown in a few studies (Hildesheim et al, 1993; LazcanoPonce et al, 2001), but has not been confirmed in others (Deacon

\footnotetext{
*Correspondence: Dr S Franceschi; E-mail: franceschi@iarc.fr

${ }^{5}$ Additional members of the International Agency for Research on Cancer Multicentric Cervical Cancer Study Group and the International Agency for Research on Cancer Human Papillomavirus Prevalence Surveys Study Group are listed in the Appendix

Received II June 2009; revised 8 July 2009; accepted 10 July 2009; published online 4 August 2009
}

et al, 2000; Shapiro et al, 2003; Khan et al, 2005; Banura et al, 2008; Hibbitts et al, 2008).

We took advantage of two large series of studies coordinated by the International Agency for Research on Cancer (IARC), that is, the IARC Multicentric Case-Control Study (Munoz et al, 2002) and the IARC HPV Prevalence Surveys (Franceschi et al, 2006), to evaluate the relationship between education level and risk of cervical cancer and HPV infection.

\section{MATERIALS AND METHODS}

\section{The IARC multicentric case-control study}

Methods have been described earlier for the 11 individual studies carried out between 1985 and 1999 that have been included in this paper (Munoz et al, 1992; Eluf-Neto et al, 1994; Chaouki et al, 1998; Chichareon et al, 1998; Ngelangel et al, 1998; Rolon et al, 2000; Santos et al, 2001; Bayo et al, 2002; Franceschi et al, 2003; Hammouda et al, 2005). Briefly, eligible cases were residents in predefined study areas, or women attending reference hospitals with incident, histologically confirmed invasive cervical cancer. A total of 2446 cases were identified, including 140 adeno- or adenosquamous invasive cervical carcinomas from six study areas 
(Eluf-Neto et al, 1994; Chaouki et al, 1998; Chichareon et al, 1998; Ngelangel et al, 1998; Rolon et al, 2000; Santos et al, 2001). Control women were population based in the Spanish and Colombian studies (Munoz et al, 1992) and hospital or clinic based in other study areas. They were frequency matched by 5 -year age group and did not include women admitted to hospital for cancers of the anogenital tract, breast and colon, smoking-related diseases (Munoz et al, 1992), or sexually transmitted infections (Hammouda et al, 2005). A total of 2390 control women were included between 1985 and 1999 (Figure 1).

\section{The IARC HPV prevalence surveys}

Sampling methods of participating women have already been described for the 16 individual studies carried out between 1993 and 2006 that are included in this paper (Molano et al, 2002; Anh et al, 2003; de Sanjose et al, 2003; Matos et al, 2003; Shin et al, 2003; Sukvirach et al, 2003; Ferreccio et al, 2004; Thomas et al, 2004; Dai et al, 2006; Li et al, 2006; Wu et al, 2007; Bardin et al, 2008; Dondog et al, 2008; Keita et al, 2009). Briefly, in each area attempts were made to obtain a population-based sample that included at least 100 women in each 5-year age group between 15 or 18 years, and 55 years or older. Participation ranged from $48 \%$ to over $90 \%$ and, overall, 15051 women were included. On account of the need to undergo a gynaecological examination, prevalence surveys were mainly restricted to women who reported to have had sexual intercourse and, in some areas, to married women. Few single women ( $6 \%$ of all study women) and only 90 virgin women were, therefore, included.

The questionnaires used in both case-control studies and prevalence surveys included a question with regard to the years of full-time education and information on lifetime number of sexual partners, age at first sexual intercourse, husband's extramarital sexual relationships, use of oral contraceptives and condom, parity, age at first pregnancy, smoking, and history of Pap smear. Among cases, any Pap smear taken less that 1 year before cancer diagnosis was excluded as they were considered 'diagnostic smears'.

All women in both studies signed informed consent forms according to the recommendations of the IARC and local ethical review committees, which approved the studies.

\section{HPV detection}

HPV testing was performed in the Department of Pathology at the Vrije University Medical Center, Amsterdam, the Netherlands, as described in individual study publications. The overall presence of HPV DNA was determined by performing a general primer GP5 + I

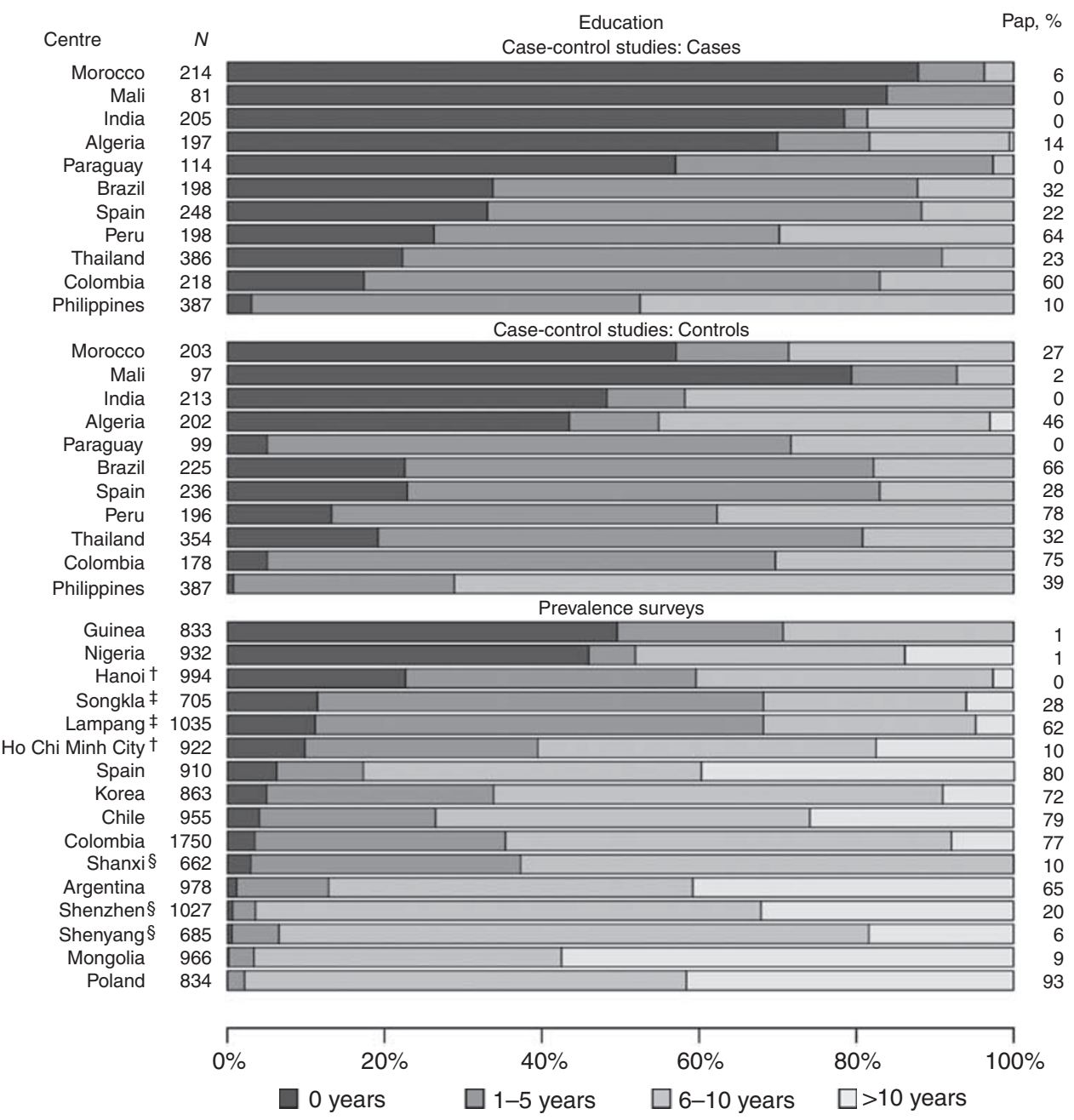

Figure I Distribution of women with and without cervical cancer in the International Agency for Research on Cancer case-control studies and human papillomavirus prevalence surveys, according to education level, Pap smear history*, and study area. *In case-control studies, Pap smears taken 12 months before enrolment are excluded. 'Study areas in Vietnam. ${ }^{\ddagger}$ Study areas in Thailand. ${ }^{\$}$ Study areas in China. 
6+-mediated PCR (Jacobs et al, 2000). HPV positivity was assessed by hybridisation of PCR products in an enzyme immunoassay using two HPV oligoprobe cocktails that, together, detect the following HPV types: HPV6, 11, 16, 18, 26, 31, 33, 34, 35, $39,40,42,43,44,45,51,52,53,54,55,56,57,58,59,61,66,68,70$, 72, 73, 82 (IS39 and MM4 subtypes), 83 (equivalent to MM7), 84 (equivalent to MM8), and CP6108. Subsequent HPV typing was performed by reverse-line blot hybridisation of PCR products, as described earlier (Jacobs et al, 1995; van den Brule et al, 2002).

\section{Statistical analysis}

Education level was classified into four groups $(0,1-5,6-10 ;>10$ years). Owing to small numbers, the last two groups were merged in the case-control studies. Regularised logistic regression (Gelman et al, 2008) was used to calculate odds ratios (ORs) and $95 \%$ confidence intervals (CIs) by education level for cervical cancer in the case-control studies and for HPV infection among control women only in case-control studies and among the general female population in prevalence surveys. The reference category for education was set to the most common category (i.e., 1-5 years in case-control studies and 6-10 years in prevalence surveys).

Tests for trend were computed using three or four categories of education level as continuous variables. All analyses were adjusted for age (in 5-year groups) and study area. Adjustment was also made for lifetime number of sexual partners $(0-1,2, \geqslant 3)$, age at first sexual intercourse $(<17,17-20, \geqslant 21$ years), husband's extramarital sexual relationships (no, yes, or uncertain), number of full-term pregnancies $(0,1-2,3-4,5-6, \geqslant 7)$, age at first pregnancy $(<18,18-20, \geqslant 21$ years), use of hormonal contraceptives and condom (never, ever), smoking (never, former, ever), and history of Pap smear (never, ever), as reported.

Heterogeneity of ORs between study areas was tested by fitting separate models to each area and then comparing the observed with the expected dispersion of estimates around the pooled mean using a $\chi^{2}$ statistic. For purposes of assessing heterogeneity, study areas with five or fewer individuals in a given category of education were not considered, as they could not provide OR estimates. All statistical tests were two-sided.

Results in the text are presented as ORs with conventional CIs. Where results are presented in the form of plots, floating absolute risks (Plummer, 2004) were used to represent the dose-response relationship in a way independent of the choice of reference category. ORs are represented by squares and their corresponding floating CIs by horizontal lines. The position of the square indicates the point estimate of the OR, and the area of the square is inversely proportional to the square of the floating standard error on the log scale, thus providing an indication of the amount of statistical information available.

\section{RESULTS}

Figure 1 shows the number of women included in each study and the broad variations in education level across study areas. Among cervical cancer cases, $82 \%$ (range: $53-100 \%$ ) reported 5 years of education or less. The percentage of women who reported 5 years of education or less was $66 \%$ (range 29-93\%) among control women in the IARC Multicentric Case-Control Study and 34\% (range: $2-71 \%$ ) among the general female population in the IARC HPV Prevalence Surveys (Figure 1). Large variations were also found in the proportion of women who reported to have had a Pap smear, averaging 23\% (range: $0-64 \%$ ) and 37\% (range: $0-78 \%$ ) among cervical cancer cases and control women, respectively, in case-control studies, and 42\% (range: $0-93 \%$ ) among women in prevalence surveys (Figure 1).

Education level was associated with cervical cancer risk (OR for 0 and $>5$ years $v s 1-5$ years $=1.50,95 \%$ CI: $1.25-1.80$; and 0.69 ,
A

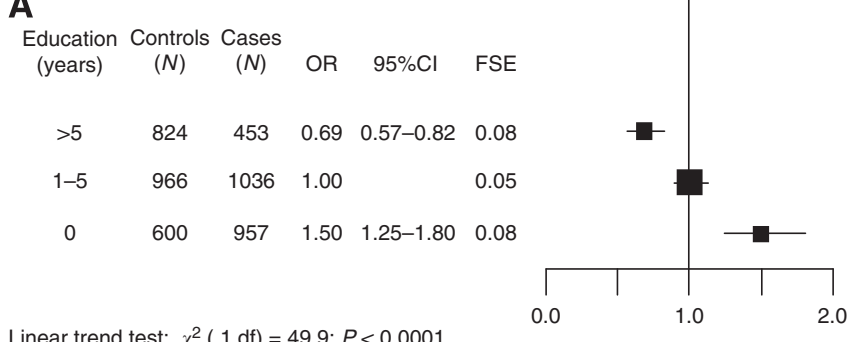

Linear trend test: $\chi^{2}(1 \mathrm{df})=49.9 \cdot P<0.0001$

Tests for heterogeneity: 0 vs $1-5$ years, $P=0.16 ; 1-5$ vs $>5$ years, $P=0.46$.

B

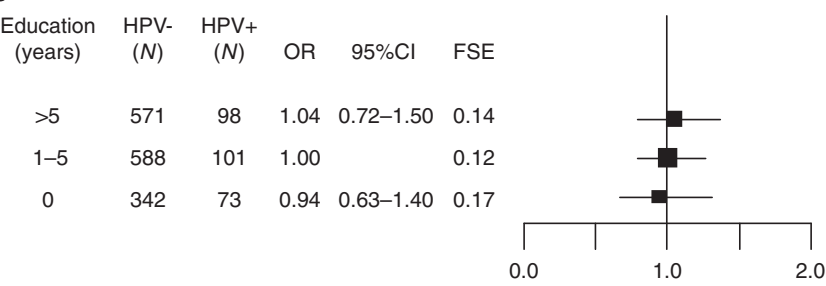

Linear trend test: $\chi^{2}(1 \mathrm{df})=0.3 ; P=0.62$

Tests for heterogeneity: 0 vs $1-5$ years, $P=0.64 ; 1-5$ vs $>5$ years, $P=0.67$.

Figure 2 Odds ratios $(\mathrm{OR})^{\dagger}$ and corresponding 95\% confidence intervals $(\mathrm{Cl})$ for $(\mathbf{A})$ cervical cancer risk and $(\mathbf{B})$ human papillomavirus (HPV) positivity among control women only. The International Agency for Research on Cancer Multicentric Case-Control Study. FSE= floating standard error, HPV = human papillomavirus. ${ }^{\dagger}$ Adjusted for age, study area, lifetime number of sexual partners, age at first sexual intercourse, husbands' extramarital sexual relationships, parity, age at first pregnancy, oral contraceptive use, and history of Pap smear.

$\begin{array}{lccccc}\begin{array}{c}\text { Education } \\ \text { (years) }\end{array} & \begin{array}{c}\text { HPV } \\ (N)\end{array} & \begin{array}{c}\mathrm{HPV}+ \\ (N)\end{array} & \text { OR } & 95 \% \mathrm{Cl} & \mathrm{FSE} \\ >10 & 2452 & 536 & 1.03 & 0.90-1.18 & 0.06 \\ 6-10 & 5918 & 1100 & 1.00 & & 0.03 \\ 1-5 & 3073 & 371 & 0.88 & 0.76-1.02 & 0.07 \\ 0 & 1231 & 370 & 1.06 & 0.87-1.28 & 0.09\end{array}$

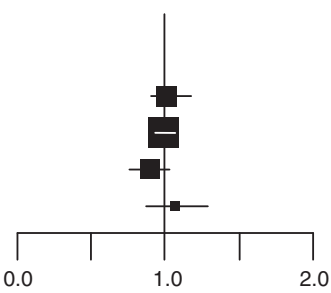

Linear trend test: $\chi^{2}(1 \mathrm{df})=0.18 ; P=0.67$

Test for heterogeneity: 0 vs $6-10$ years, $P=0.99 ; 1-5$ vs $6-10$ years, $P=0.96$ $>10$ vs $6-10$ years, $P=0.26$.

Figure 3 Odds ratios $(\mathrm{OR})^{\dagger}$ and corresponding 95\% confidence intervals $(\mathrm{Cl})$ for human papillomavirus (HPV) positivity by education level. The International Agency for Research on Cancer HPV Prevalence Surveys. FSE = floating standard error. ${ }^{\dagger}$ Adjusted for age, study area, lifetime number of sexual partners, age at first sexual intercourse, husbands' extramarital sexual relationships and history of Pap smear.

95\% CI: $0.57-0.82$, respectively, $P$ for trend $<0.0001)$ in casecontrol studies (Figure 2A). The association was similar in all study areas and no statistically significant heterogeneity emerged. When the association between education level and risk of adenoor adenosquamous carcinoma was evaluated separately, findings were similar to those for all cervical cancers (OR for 0 and $>5$ years $v s 1-5$ years $=1.80,95 \%$ CI: $1.11-2.91$; and $0.76,95 \% \mathrm{CI}$ : $0.47-1.24$, respectively, data not shown). In contrast, education level was not associated with HPV positivity among control women (OR for 0 and $>5$ years $v s 1-5$ years $=1.04,95 \%$ CI: $0.63-1.40$; and $0.94,95 \%$ CI: $0.63-1.40$ ) (Figure 2B).

In agreement with the findings among control women in the case-control studies, no association between education level and HPV positivity was found among the larger number of women included in the prevalence surveys (OR for $>10,1-5$, and 0 years vs $6-10$ years $=1.03,95 \%$ CI: $0.90-1.18 ; 0.88,95 \%$ CI: $0.76-1.02$; and $1.06,95 \%$ CI: $0.87-1.28$, respectively, $P$ for trend $=0.67$ ) 
Table I Effect of adjustment by potential confounding factors on the odds ratio (OR) of cervical cancer by education level

\begin{tabular}{ll} 
Adjustment variables & $\begin{array}{c}\text { OR } \mathbf{( 9 5 \%} \mathbf{~ C l}) \\
\mathbf{5} \text { vs } \mathbf{5} \text { years } \\
\text { of education }\end{array}$ \\
\hline Age+study area & $2.64(2.27-3.06)$ \\
As above+ & \\
Lifetime number of sexual partners & $2.55(2.19-2.97)$ \\
Age at first intercourse & $2.03(1.73-2.37)$ \\
Husband's extramarital sexual relationships & $2.62(2.21-3.11)$ \\
Parity & $2.22(1.90-2.59)$ \\
Age at first pregnancy & $2.13(1.80-2.52)$ \\
Oral contraceptive use & $2.40(2.02-2.84)$ \\
Condom use & $2.61(2.25-3.03)$ \\
Smoking & $2.65(2.28-3.08)$ \\
History of Pap smear & $2.25(1.92-2.62)$ \\
All the above (except condom use and smoking) & $1.41(1.11-1.79)$ \\
\hline
\end{tabular}

$\mathrm{Cl}=$ confidence interval.

(Figure 3). Although some differences emerged across study areas with some non-statistically significant associations in either direction, no significant heterogeneity was found between study areas with respect to HPV infection and education level.

The influence of adjusting for different confounding variables on the association between cervical cancer risk and education (dichotomised as $\leqslant 5$ and $>5$ years) in the case-control studies is shown in Table 1 . The age- and study area-adjusted OR $(2.64,95 \%$ CI: 2.27-3.06) was most strongly attenuated by adjustment for age at first sexual intercourse $(\mathrm{OR}=2.03,95 \% \mathrm{CI}: 1.73-2.37)$ and age at first pregnancy $(\mathrm{OR}=2.13,95 \% \mathrm{CI}: 1.80-2.52)$. Adjustment for parity, use of oral contraceptives, and history of Pap smear also somewhat diminished the OR by education level, whereas adjustment for lifetime number of sexual partners, husband's extramarital sexual relationships, condom use, and tobacco smoking did not. The fully adjusted OR for $\leqslant 5 v s>5$ years of education was 1.41 (95\% CI: $1.11-1.79)$, that is, $47 \%$ lower than the OR adjusted for age and study area only.

\section{DISCUSSION}

Education level was inversely and consistently associated with cervical cancer risk, but not with HPV prevalence, in a broad range of world populations included in the IARC studies. The lack of excess of HPV positivity in low-education women was consistently found among control women in case-control studies (i.e., in the same population in which the association between low-education level and cervical excess risk emerged), as well as in the larger number of women included in the HPV prevalence surveys that were carried out in part in different countries than the casecontrol studies.

Obviously, education level cannot be considered as a welldefined exposure, but as a marker for a combination of characteristics that predominate among women with a low SES. The aim of our study was not, therefore, to rule out bias and confounding, but rather to evaluate the principal risk factors responsible for any socio-economic gradient.

In screened populations, education level is most likely to be a surrogate of inadequate screening (Khan et al, 2005), but a socio- economic gradient in cervical cancer risk was reported long before screening programmes were introduced (Jones et al, 1958) and is still seen in countries where little screening activity exists (Franceschi et al, 2003; Parikh et al, 2003). Such was the case in our combined analysis; although in some study areas, a large fraction of women who reported to have had at least one Pap smear taken in their lifetime and screening history did have an influence on the association with education level, nowhere did broad-coverage and high-quality screening programmes exist at the time our studies took place (Konno et al, 2008; Murillo et al, 2008).

A substantial fraction of the influence of socio-economic gradient on cervical cancer risk in our study was explained by the early age of first sexual intercourse and first pregnancy (Louie et al, 2009), as well as by high parity, whereas lifetime number of sexual partners and husband's extramarital sexual relationships did not seem to be important confounding factors. Similarly, adjustment for the presence of HPV infection among cervical cancer cases and controls or restriction to HPV-positive women, as carried out in some earlier reports from the IARC case-control study (Munoz et al, 2002), left the association with low education level unchanged (data not shown).

The weaknesses of this study include the limitation in the completeness and quality of information available on SES, which led us to use education level only as a proxy of SES, and on possible confounding factors, notably sexual behaviour and screening history. Residual confounding, therefore, probably still inflates the association between cervical cancer risk and education in our report. This problem does not eclipse, however, the clear difference we found between cervical cancer and HPV positivity with respect to SES. Additional information on SES (e.g., income, ownership of the house, and number of appliances and facilities at home) and husband's sexual behaviour (e.g., sexual intercourses with prostitutes) (de Sanjose et al, 1997) was included in some studies that are a part of this report. These variables, however, were missing for a substantial proportion of women and, in the case of SES indicators, were highly correlated with education level. The strengths of this study are the large number of women included, the performance of high-quality HPV testing, and the relatively modest impact of cervical cancer screening in the majority of populations in which IARC studies have been performed that allowed other correlates of low education level other than screening to emerge more clearly.

Our findings imply that higher HPV prevalence and lifetime number of sexual partners do not explain the excess of cervical cancer in women with low SES. Conversely, early events that can modify the carcinogenic potential of HPV infection, such as early age of first intercourse (a possible proxy of longer duration of uncleared HPV infection (International Collaboration of Epidemiological Studies of Cervical Cancer, 2009)) and early and multiple pregnancies (International Collaboration of Epidemiological Studies of Cervical Cancer, 2006) account for a large part of the SES gradient of cervical cancer, at least in inadequately screened populations.

\section{ACKNOWLEDGEMENTS}

This work was supported by the Bill and Melinda Gates Foundation (grant number 35537).

\section{REFERENCES}

Anh PT, Hieu NT, Herrero R, Vaccarella S, Smith JS, Thuy NT, Nga NH, Duc NB, Ashley R, Snijders PJ, Meijer CJ, Munoz N, Parkin DM, Franceschi S (2003) Human papillomavirus infection among women in South and North Vietnam. Int J Cancer 104: 213-220
Banura C, Franceschi S, van Doorn LJ, Arslan A, Wabwire-Mangen F, Mbidde EK, Quint W, Weiderpass E (2008) Infection with human papillomavirus and HIV among young women in Kampala, Uganda. J Infect Dis 197: 555-562 
Bardin A, Vaccarella S, Clifford GM, Lissowska J, Rekosz M, Bobkiewicz P, Kupryjanczyk J, Krynicki R, Jonska-Gmyrek J, Danska-Bidzinska A, Snijders PJ, Meijer CJ, Zatonski W, Franceschi S (2008) Human papillomavirus infection in women with and without cervical cancer in Warsaw, Poland. Eur J Cancer 44: 557-564

Bayo S, Bosch FX, de Sanjose S, Munoz N, Combita AL, Coursaget P, Diaz M, Dolo A, van den Brule AJ, Meijer CJ (2002) Risk factors of invasive cervical cancer in Mali. Int J Epidemiol 31: 202-209

Chaouki N, Bosch FX, Munoz N, Meijer CJ, El Gueddari B, El Ghazi A, Deacon J, Castellsague X, Walboomers JM (1998) The viral origin of cervical cancer in Rabat, Morocco. Int J Cancer 75: 546-554

Chichareon S, Herrero R, Munoz N, Bosch FX, Jacobs MV, Deacon J, Santamaria M, Chongsuvivatwong V, Meijer CJ, Walboomers JM (1998) Risk factors for cervical cancer in Thailand: a case-control study. J Natl Cancer Inst 90: $50-57$

Dai M, Bao YP, Li N, Clifford GM, Vaccarella S, Snijders PJF, Huang RD, Sun LX, Meijer CJLM, Qiao YL, Franceschi S (2006) Human papillomavirus infection in Shanxi Province, People's Republic of China: a population-based study. $\mathrm{Br}$ J Cancer 95: 96-101

de Sanjose S, Almirall R, Lloveras B, Font R, Diaz M, Munoz N, Catala I, Meijer CJ, Snijders PJ, Herrero R, Bosch FX (2003) Cervical human papillomavirus infection in the female population in Barcelona, Spain. Sex Transm Dis 30: 788-793

de Sanjose S, Bosch FX, Munoz N, Shah K (1997) Social differences in sexual behaviour and cervical cancer. IARC Sci Publ 138: 309-317

Deacon JM, Evans CD, Yule R, Desai M, Binns W, Taylor C, Peto J (2000) Sexual behaviour and smoking as determinants of cervical HPV infection and of CIN3 among those infected: a case-control study nested within the Manchester cohort. Br J Cancer 83: $1565-1572$

Dondog B, Clifford GM, Vaccarella S, Waterboer T, Unurjargal D, Avirmed D, Enkhtuya S, Kommoss F, Wentzensen N, Snijders PJ, Meijer CJ, Franceschi S, Pawlita M (2008) Human papillomavirus infection in Ulaanbaatar, Mongolia: a population-based study. Cancer Epidemiol Biomarkers Prev 17: $1731-1738$

Eluf-Neto J, Booth M, Munoz N, Bosch FX, Meijer CJ, Walboomers JM (1994) Human papillomavirus and invasive cervical cancer in Brazil. $\mathrm{Br} \mathrm{J}$ Cancer 69: $114-119$

Ferreccio C, Prado RB, Luzoro AV, Ampuero SL, Snijders PJ, Meijer CJ, Vaccarella S, Jara AT, Puschel KI, Robles SC, Herrero R, Franceschi S, Ojeda JM (2004) Population-based prevalence and age distribution of human papillomavirus among women in Santiago, Chile. Cancer Epidemiol Biomarkers Prev 13: 2271-2276

Franceschi S, Herrero R, Clifford GM, Snijders PJ, Arslan A, Anh PT, Bosch FX, Ferreccio C, Hieu NT, Lazcano-Ponce E, Matos E, Molano M, Qiao YL, Rajkumar R, Ronco G, de Sanjose S, Shin HR, Sukvirach S, Thomas JO, Meijer CJ, Munoz N, the IARC HPV Prevalence Surveys Study Group (2006) Variations in the age-specific curves of human papillomavirus prevalence in women worldwide. Int J Cancer 119: 2677 -2684

Franceschi S, Rajkumar T, Vaccarella S, Gajalakshmi V, Sharmila A, Snijders PJ, Munoz N, Meijer CJ, Herrero R (2003) Human papillomavirus and risk factors for cervical cancer in Chennai, India: a case-control study. Int J Cancer 107: 127-133

Gelman A, Jakulin A, Pittau MG, Su YS (2008) A weakly informative default prior distribution for logistic and other regression models. Ann Appl Stat 2: $1360-1383$

Hammouda D, Munoz N, Herrero R, Arslan A, Bouhadef A, Oublil M, Djedeat B, Fontaniere B, Snijders P, Meijer C, Franceschi S (2005) Cervical carcinoma in Algiers, Algeria: human papillomavirus and lifestyle risk factors. Int J Cancer 113: 483-489

Hibbitts S, Jones J, Powell N, Dallimore N, McRea J, Beer H, Tristram A, Fielder H, Fiander AN (2008) Human papillomavirus prevalence in women attending routine cervical screening in South Wales, UK: a crosssectional study. Br J Cancer 99: 1929-1933

Hildesheim A, Gravitt P, Schiffman MH, Kurman RJ, Barnes W, Jones S, Tchabo JG, Brinton LA, Copeland C, Epp J (1993) Determinants of genital human papillomavirus infection in low-income women in Washington, D.C. Sex Transm Dis 20: 279-285

International Collaboration of Epidemiological Studies of Cervical Cancer (2006) Cervical carcinoma and reproductive factors: collaborative reanalysis of individual data on 16,563 women with cervical carcinoma and 33,542 women without cervical carcinoma from 25 epidemiological studies. Int J Cancer 119: 1108 - 1124

International Collaboration of Epidemiological Studies of Cervical Cancer (2009) Cervical carcinoma and sexual behavior: collaborative reanalysis of individual data on 15,461 women with cervical carcinoma and 29,164 women without cervical carcinoma from 21 epidemiological studies. Cancer Epidemiol Biomarkers Prev 18: $1060-1069$

Jacobs MV, Roda Husman AM, van den Brule AJ, Snijders PJ, Meijer CJ, Walboomers JM (1995) Group-specific differentiation between high- and low-risk human papillomavirus genotypes by general primer-mediated PCR and two cocktails of oligonucleotide probes. J Clin Microbiol 33: 901-905

Jacobs MV, Walboomers JM, Snijders PJ, Voorhorst FJ, Verheijen RH, Fransen-Daalmeijer N, Meijer CJ (2000) Distribution of 37 mucosotropic HPV types in women with cytologically normal cervical smears: the age-related patterns for high-risk and low-risk types. Int J Cancer 87: $221-227$

Jones EG, MacDonald I, Breslow L (1958) A study of epidemiologic factors in carcinoma of the uterine cervix. Am J Obstet Gynecol 76: 1-10

Keita N, Clifford GM, Koulibaly M, Douno K, Kabba I, Haba M, Sylla BS, van Kemenade FJ, Snijders PJ, Meijer CJ, Franceschi S (2009) HPV infection in women with and without cervical cancer in Conakry, Guinea. Br J Cancer 101(1): $202-208$.

Khan MJ, Partridge EE, Wang SS, Schiffman M (2005) Socioeconomic status and the risk of cervical intraepithelial neoplasia grade 3 among oncogenic human papillomavirus DNA-positive women with equivocal or mildly abnormal cytology. Cancer 104: $61-70$

Konno R, Shin HR, Kim YT, Song YS, Sasagawa T, Inoue M, Park JS (2008) Human papillomavirus infection and cervical cancer prevention in Japan and Korea. Vaccine 26(Suppl 12): M30-M42

Lazcano-Ponce E, Herrero R, Munoz N, Cruz A, Shah KV, Alonso P, Hernandez P, Salmeron J, Hernandez M (2001) Epidemiology of HPV infection among Mexican women with normal cervical cytology. Int $J$ Cancer 91: $412-420$

Li LK, Dai M, Clifford GM, Yao WQ, Arslan A, Li N, Shi JF, Snijders PJ, Meijer CJ, Qiao YL, Franceschi S (2006) Human papillomavirus infection in Shenyang City, People's Republic of China: a population-based study. Br J Cancer 95: $1593-1597$

Louie KS, de Sanjose S, Diaz M, Castellsague X, Herrero R, Meijer CJ, Shah K, Franceschi S, Munoz N, Bosch FX (2009) Early age at first sexual intercourse and early pregnancy are risk factors for cervical cancer in developing countries. Br J Cancer 100: $1191-1197$

Matos E, Loria D, Amestoy G, Herrera L, Prince MA, Moreno J, Krunfly C, van den Brule AJ, Meijer CJ, Munoz N, Herrero R, Proyecto Concordia Collaborative Group (2003) Prevalence of human papillomavirus infection among women in Concordia, Argentina: a population-based study. Sex Transm Dis 30: 593 - 599

Molano $M$, Posso $H$, Weiderpass $E$, van den Brule AJ, Ronderos $M$, Franceschi S, Meijer CJ, Arslan A, Munoz N, the HPV Study Group (2002) Prevalence and determinants of HPV infection among Colombian women with normal cytology. Br J Cancer 87: 324-333

Munoz N, Bosch FX, de Sanjose S, Tafur L, Izarzugaza I, Gili M, Viladiu P, Navarro C, Martos C, Ascunce N (1992) The causal link between human papillomavirus and invasive cervical cancer: a population-based casecontrol study in Colombia and Spain. Int J Cancer 52: 743-749

Munoz N, Franceschi S, Bosetti C, Moreno V, Herrero R, Smith JS, Shah KV, Meijer CJ, Bosch FX, for the IARC Multicentric Cervical Cancer Study Group (2002) Role of parity and human papillomavirus in cervical cancer: the IARC multicentric case-control study. Lancet 359: $1093-1101$

Murillo R, Almonte M, Pereira A, Ferrer E, Gamboa OA, Jeronimo J, Lazcano-Ponce E (2008) Cervical cancer screening programs in Latin America and the Caribbean. Vaccine 26(Suppl 11): L37-L48

Ngelangel C, Munoz N, Bosch FX, Limson GM, Festin MR, Deacon J, Jacobs MV, Santamaria M, Meijer CJ, Walboomers JM (1998) Causes of cervical cancer in the Philippines: a case-control study. J Natl Cancer Inst 90: $43-49$

Parikh S, Brennan P, Boffetta P (2003) Meta-analysis of social inequality and the risk of cervical cancer. Int J Cancer 105: 687-691

Plummer M (2004) Improved estimates of floating absolute risk. Stat Med 23: $93-104$

Rolon PA, Smith JS, Munoz N, Klug SJ, Herrero R, Bosch X, Llamosas F, Meijer CJ, Walboomers JM (2000) Human papillomavirus infection and invasive cervical cancer in Paraguay. Int J Cancer 85: 486-491

Santos C, Munoz N, Klug S, Almonte M, Guerrero I, Alvarez M, Velarde C, Galdos O, Castillo M, Walboomers J, Meijer C, Caceres E (2001) HPV types and cofactors causing cervical cancer in Peru. Br J Cancer 85: $966-971$

Schiffman M, Castle PE, Jeronimo J, Rodriguez AC, Wacholder S (2007) Human papillomavirus and cervical cancer. Lancet 370: 890-907 
Shapiro S, Carrara H, Allan BR, Hoffman M, Rosenberg L, Kelly JP, Cooper DD, Williamson AL (2003) Hypothesis: the act of taking a Papanicolaou smear reduces the prevalence of human papillomavirus infection: a potential impact on the risk of cervical cancer. Cancer Causes Control 14: 953-957

Shin HR, Lee DH, Herrero R, Smith JS, Vaccarella S, Hong SH, Jung KY, Kim HH, Park UD, Cha HS, Park S, Touze A, Munoz N, Snijders PJ, Meijer CJ, Coursaget P, Franceschi S (2003) Prevalence of human papillomavirus infection in women in Busan, South Korea. Int J Cancer 103: $413-421$

Sukvirach S, Smith JS, Tunsakul S, Munoz N, Kesararat V, Opasatian O, Chichareon S, Kaenploy V, Ashley R, Meijer CJ, Snijders PJ, Coursaget P, Franceschi S, Herrero R (2003) Population-based human papillomavirus prevalence in Lampang and Songkla, Thailand. J Infect Dis 187: 1246-1256
Thomas JO, Herrero R, Omigbodun AA, Ojemakinde K, Ajayi IO, Fawole A, Oladepo O, Smith JS, Arslan A, Munoz N, Snijders PJ, Meijer CJ, Franceschi S (2004) Prevalence of papillomavirus infection in women in Ibadan, Nigeria: a population-based study. Br J Cancer 90: 638-645 van den Brule AJ, Pol R, Fransen-Daalmeijer N, Schouls LM, Meijer CJ, Snijders PJ (2002) GP5+/6+ PCR followed by reverse line blot analysis enables rapid and high-throughput identification of human papillomavirus genotypes. J Clin Microbiol 40: $779-787$

Wu RF, Dai M, Qiao YL, Clifford GM, Liu ZH, Arslan A, Li N, Shi JF, Snijders PJ, Meijer CJ, Franceschi S (2007) Human papillomavirus infection in women in Shenzhen City, People's Republic of China, a population typical of recent Chinese urbanisation. Int J Cancer 121: $1306-1311$

\section{Appendix}

In addition to the aforementioned, the members of the IARC Multicentric Case-Control Study Group are (in alphabetical order by country): Algeria (D Hammouda); Brazil (J Eluf-Neto); Colombia (N Aristizabal, LA Tafur); India ( $\mathrm{T}$ Rajkumar); Mali (S Bayo); Morocco (N Chaouki, B El Gueddari); the Netherlands (CJLM Meijer, PJF Snijders, AJC van den Brule, JMM Walboomers); Paraguay (PA Rolón); Peru (E Caceres, C Santos); the Philippines (C Ngelangel); Spain (N Ascunce, X Castellsagué, $\mathrm{M}$ Gili, LC González, I Izarzugaza, C Navarro, M Santamaria); Thailand (S Chichareon); and the United States (KV Shah).

In addition to the aforementioned, the members of the IARC Human Papillomavirus Prevalence Surveys Study Group are (in alphabetical order by country): Argentina (D Loria, E Matos); Chile (C Ferreccio, A Luzoro, JM Ojeda, R Prado); China (M Dai, N Li, YL Qiao, RF Wu); Colombia (M Molano, $\mathrm{H}$ Posso); France (A Arslan); Guinea (N Keita); Korea (D-H Lee, H R Shin); Mongolia (B Dondog, M Pawlita); Nigeria (A Omigbodun, JO Thomas); Poland (A Bardin, W Zatonski); Thailand (S Sukvirach, S Tunsakul); The Netherlands (CJLM Meijer, PJF Snijders); the United States (J Smith); and Vietnam (PTH Anh, NT Hieu). 